\title{
3 The New Normal of Chinese Development
}

Yiping Huang, Cai Fang, Peng Xu and Gou Qin

\section{China's New Transition}

China's economic performance during the reform period is sometimes described as a miracle (Lin et al. 1995). Its GDP per capita increased from US $\$ 220$ in 1980 to US\$6,000 in 2012. Not only is it now the world's second largest economy, but it also contributes at least one-third of global economic growth in recent years. China is already a major player in global markets for luxury goods, labour-intensive manufacturing exports, commodities and foreign exchange. Many economists are optimistic that China can continue its rapid economic growth, albeit at a somewhat slower pace, in the coming decades (Perkins and Rawski 2008; Lin 2011).

Structural risks, however, also grow over time, dimming China's economic outlook. Former premier Wen Jiabao once described the growth model as 'uncoordinated, imbalanced, inefficient and unsustainable' (see, for example, Wen 2006). The structural problems include the over-dependence of economic growth on external demand, continuous decline of the consumption share of GDP, worsening income distribution and devastating pollution. The investment rate rose steadily from around 25 per cent at the beginning of economic reform, to close to 50 per cent after the global financial crisis.

One consensus view that is shared by most economists is that this growth model needs to change in order for China's rapid economic growth to continue (Yu 2009; Huang 2010). Shortly after taking office in 2003, Wen vowed to take policy steps to improve growth quality; but general assessment is that those efforts achieved little in changing the growth model. In fact, many economists believe that the imbalance problems have become worse during the past decade (Lardy 2012). Some analysts argue that correction of such structural risks necessarily requires substantially slower growth, if not collapse, of the Chinese economy (Pettis 2013):

China will be the last major economy to emerge from the global crisis. ... I think it is pretty clear that over the next few years China will be forced to address and reverse the high saving rate, ... This may take a decade or more. ... If the transition is not mismanaged, average Chinese GDP growth rates will drop to $3 \%$ for the 2010-20 decade. 
This chapter argues that important changes to the Chinese growth model are already underway. Evidence shows that the Chinese economy is transitioning toward the 'new normal', involving slower but more sustainable economic growth, although this process is still at an early stage (Huang 2012). Growth potential probably lowered from ten per cent during the first decade of the twenty-first century, to six-eight per cent during the second decade. In the meantime, current account surplus narrowed significantly; the consumption share of GDP started to rebound; and even income distribution began to improve steadily. ${ }^{1}$

Second, we suggest that the primary drivers of the transition of the growth model are changes in factor markets, especially labour market changes. China's economic reform approach is sometimes described as 'asymmetric liberalisation', which freed up the product markets but continued with distortions in the factor markets (Huang 2010). Such cost distortions included such examples as subsidies to the corporates, but taxes on households, which contributes to the imbalance, and inequality and inefficiency problems, as well as strong economic growth (Huang and Tao 2010; Huang and Wang 2010). Emerging labour shortages and associated rapid wage increases in recent years are largely responsible for the current transition to the 'new normal', with slower growth but more balanced structure.

And, third, we make some policy recommendations for the Chinese economy to complete transformation of the growth model and to avoid the 'middleincome trap'. The next-step reforms should focus on redefining the relationship between the government and the market. The first is to complete the transition to a market economy by liberalising the factor markets. The second is to establish macroeconomic policy frameworks that are compatible with emerging market economies. And the third is to change the government's role from directly supporting production and investment to facilitating innovation and upgrading.

\section{Slowing of GDP Growth}

The Chinese economy has shown significant transformation in recent years, including the steady downward shift of trend growth and rebalancing of economic structure. Some structural changes, such as narrowing of the current account surplus, are well documented in official statistics. Some improvements, such as rising share of consumption in GDP, are not captured by the official data. Yet some other adjustments, such as improvement in income distribution,

1 'Michael Pettis makes 12 Fearless Predictions about China', 2012, Business Insider, 16 April, http://www. businessinsider.com/michael-pettis-makes-12-fearless-predictions-about-china-2012-4 
are confirmed by official estimation but strongly rejected by many economists. We think that the structural improvements are real and driven primarily by changes in factor markets.

GDP growth started to decelerate in 2011, partly due to the tightening of policies by the authorities. Toward the end of the first quarter in 2012, however, it became clear that growth might soon fall below eight per cent. From March that year, the government undertook a number of steps to stabilise economic growth, including support to on-going infrastructure projects in areas of water, power and transportation. Despite this policy effort, GDP growth decelerated continuously from 8.1 per cent in the first quarter to 7.4 per cent in the third quarter.

In retrospect, two special factors probably contributed to this continuous slowdown. One, export growth fell from close to eight per cent during the first half of the year to around two per cent during July-August period. And, two, housing purchase restriction (HPR), which was introduced in April 2011, led to slowing of residential property investment growth to below ten per cent during the third quarter of 2012, from above 30 per cent a year ago. Growth deceleration caused renewed fears among international investors for a hard landing of Chinese growth. Many financial market participants repeatedly called for aggressive policy actions to support growth.

The policymakers, however, stayed relatively calm and appeared to be willing to tolerate somewhat slower growth for three reasons (Huang 2012). First, many government officials became reluctant to adopt aggressive measures supporting growth after implementation of the four trillion yuan stimulus package during the global financial crisis. The package was beginning to successfully turn around economic growth in 2009. Many economists, however, argued that it increased fiscal risks, created nonperforming loans, contributed to overcapacity in some infrastructure areas and caused inflation and asset bubbles. When growth slowed again from late 2011 , the policymakers were cautious not to overstimulate the economy.

Second, economic studies estimate China's current growth potential at sixeight per cent. The World Bank's estimates were 8.6 per cent in 2011-2015 and seven per cent in 2016-2020 (WB \& DRC 2012). Cai Fang and Lu Yang (2012) estimate China's growth potential at 7.2 per cent during 2010-2015 and six per cent during 2016-2020 (Figure 3.1). In a recent multi-country review of growth performance, Barry Eichengreen, Donghyun Park and Kwanho Shin (2011) project China to grow by 6.1 to seven per cent in the 2011-2020 decade and by five to 6.2 per cent in the period 2021-2030. Similarly, a joint 
report by the Asian Development Bank and Peking University estimates the growth potential at eight per cent in 2011-2020 and six per cent in 2021-2030 (Zhuang, Vandenberg and Huang 2012).

Figure 3.1 Estimates of growth potentials (\%)

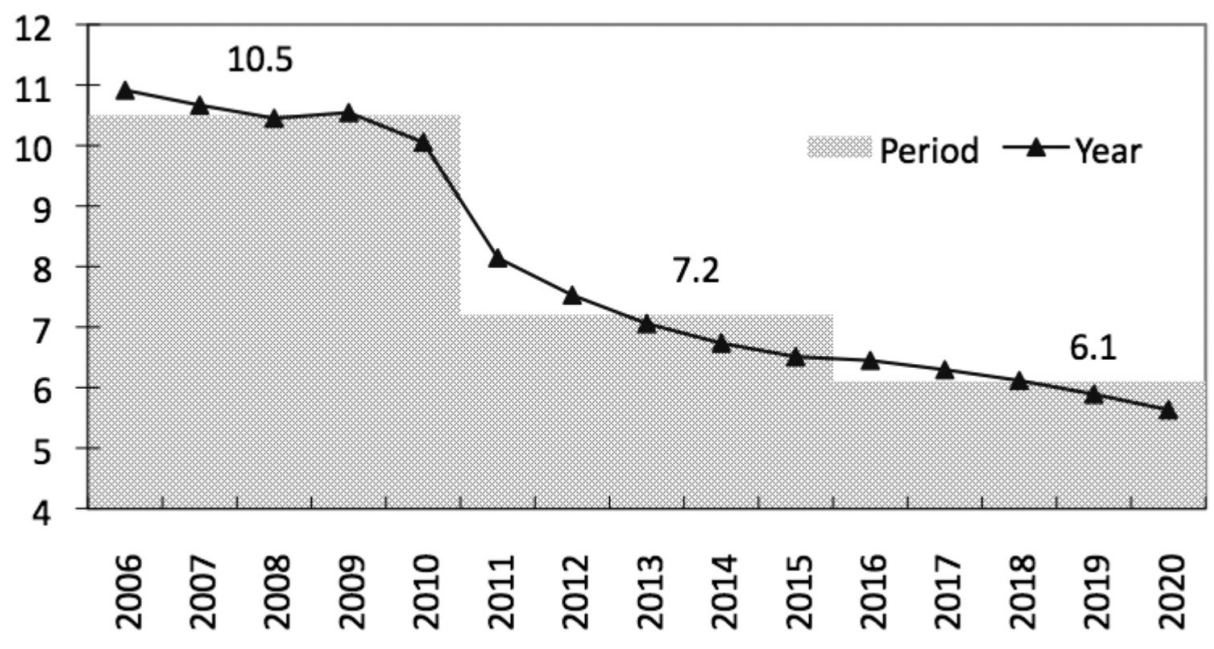

Source: Cai and Lu (2012).

And, third, economic indicators such as employment and inflation also suggested no need for aggressive policy easing, despite deceleration of GDP growth to levels below eight per cent. CPI inflation first eased, from 4.5 per cent in January, down to the trough of 1.7 per cent in October, but then picked up slowly to above two per cent in the following months. The labour market was also surprisingly resilient. In 2012, the economy created 12.7 million new jobs, despite growth slowdown. The number of migrant workers reached 163 million, up 4.7 million from a year ago and the total number of farmers employed in nonfarm jobs increased to 263 million, with an increase of 9.8 million within the year. In 25 provinces, minimum wages were adjusted, lifting the national average by 20.2 per cent; and migrant workers' monthly wages averaged 2290 yuan or US\$363, up 11.8 per cent from a year ago.

Policymakers, therefore, are no longer keen in supporting above eight per cent growth. This is mainly because growth potential is already much lower, due to the higher level of economic development and tightening condition of the labour market. For instance, in 2012, the working-age population declined by 3.5 million. The purpose of the cautious macroeconomic policy can be viewed as a strategy to allow growth to settle around its new potential. Of course, if unemployment rate rises unexpectedly, it is likely that the government will once again engage in more aggressive policies to support economic growth. 


\section{Rebalancing of the Economy}

The so-called 'new normal', however, is more than growth slowdown. Recent years have also indicated that the economy also shows clear signs of rebalancing. For instance, the current account surplus narrowed from 10.8 per cent of GDP in 2007, to 2.8 per cent in 2011 and 2.6 per cent in 2012 (Figure 3.2). Mainly because of this, the People's Bank of China (PBoC) Deputy Governor Yi Gang argued that the yuan exchange rate was near equilibrium, while US President Barak Obama's former top economic advisor, Lawrence Summers, noted in January 2013 that the yuan was not as undervalued as it was five years earlier. In recent years, two-way movement of the exchange rate and two-directional capital flows started to emerge in China.

Figure 3.2 Current account surplus as a share of GDP, 2006-2012 (\%)

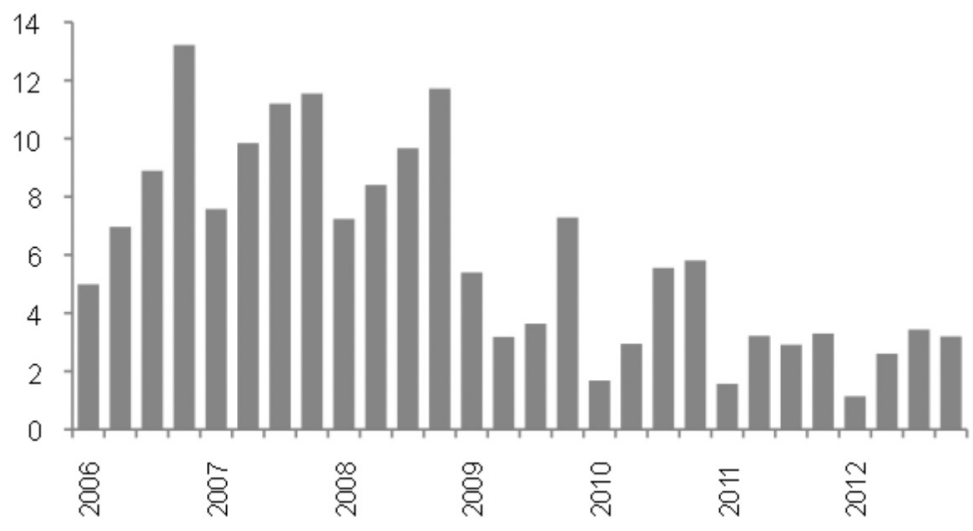

Source: National Bureau of Statistics.

Another rebalancing in recent years relates to regional disparity, with the rural-urban income gap narrowing notably (Figure 3.3). This is the result of a combination of stronger policy support to agriculture, more rapid increases in agricultural prices and steady improvement in rural productivity. In addition, China's reform success was, until recently, a story of the coastal regions. Inland economies, however, are now growing faster than the coastal economies as a result of the government's 'go west' policy, the migration of manufacturing industries, and rich resource endowments in western China (Figure 3.4). 
Figure 3.3 Urban-rural income ratio narrowed, 1987-2012 (\%)

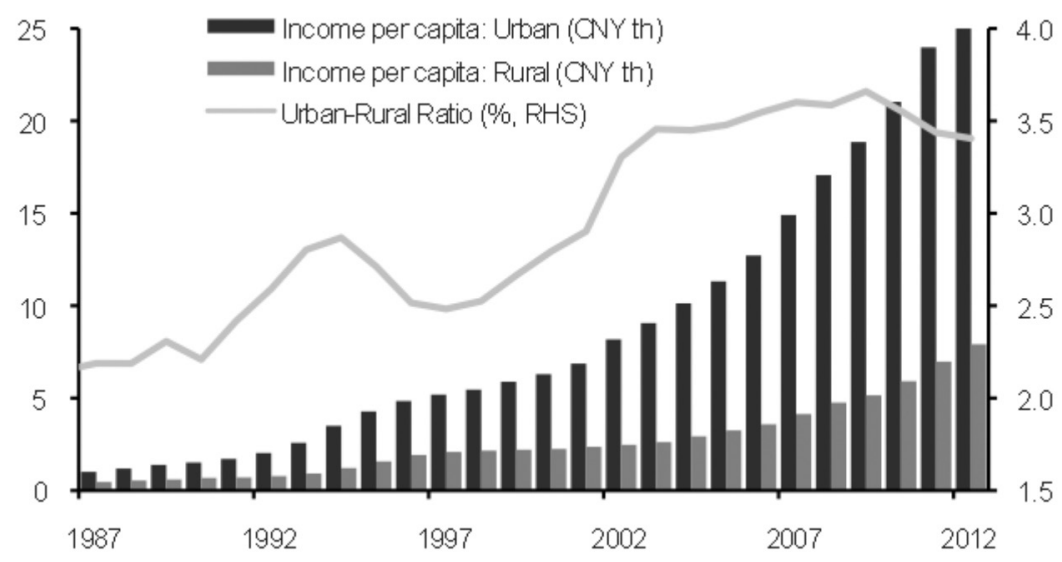

Source: CEIC Data Company.

Figure 3.4 Growth in eastern, central and western China, 2012 (\%)

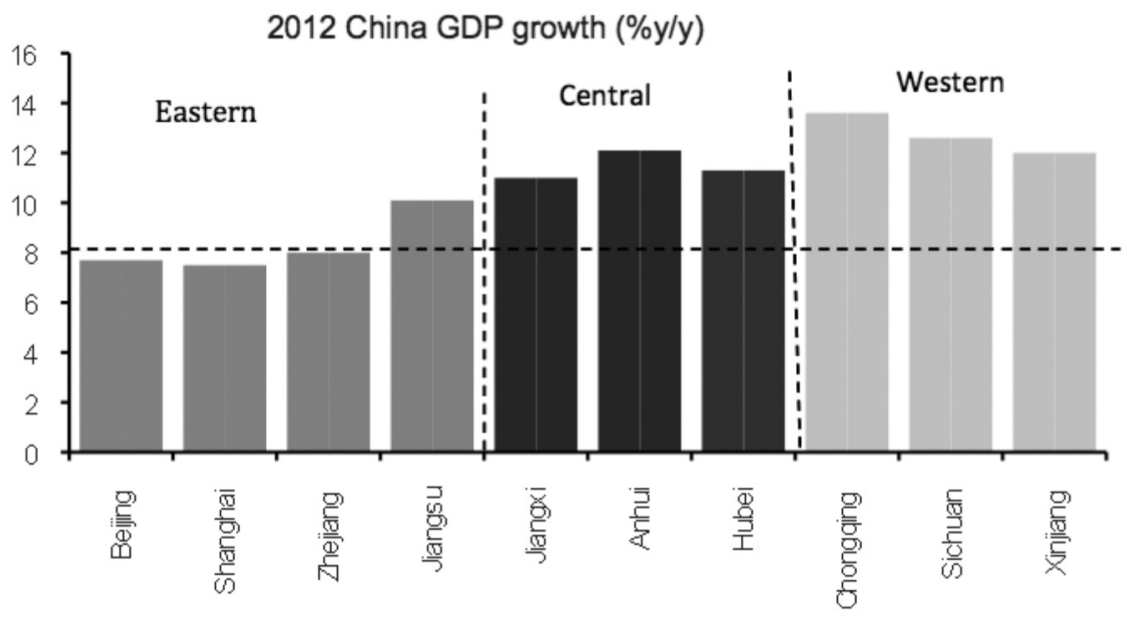

Source: CEIC Data Company.

In mid-January 2013, the Chinese National Bureau of Statistics (NBS) reported estimates of Gini coefficients for 2003-2012, which show a steady deterioration of income distribution from 0.479 in 2003 to 0.491 in 2008 and steady improvement after that, to 0.474 in 2012 (Figure 3.5). ${ }^{2}$ This, if confirmed, could mark another important turning point in China's economic development, although many Chinese economists remain sceptical about the results.

2 The Gini coefficient is a measure of income inequality - the higher the estimate, the more unequal the income distribution. 
For instance, a recent study by Southwest University of Economics and Finance reported a Gini coefficient of 0.61 in 2010. One criticism of the official NBS finding was that is did not consider income equality in household wealth, such as property. Another was under-reporting of income at the high end.

Figure 3.5 Gini coefficients estimated by the National Bureau of Statistics, 2003-2012

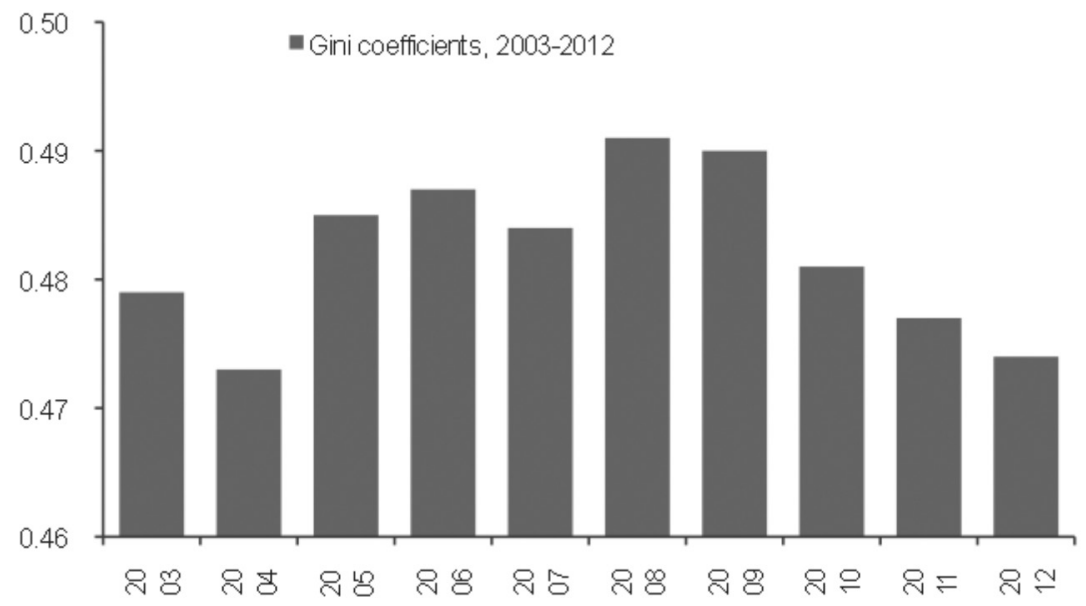

Source: National Bureau of Statistics.

Official data also suggest that the contribution of consumption to GDP growth increased from about one-third in 2007, to 52 per cent in 2012 (Figure 3.6). Two Chinese economists, Tian Zhu and Jun Zhang of Shanghai, have gone further, arguing that China's consumption share is grossly underestimated as a result of underreported residential spending, consumption covered by institutional spending and technical issues in the household survey method. They note that the consumption share estimated by the Penn World Table was 60.9 per cent in 2010, compared with the official figure of 47.4 per cent, and 58.9 per cent in the Penn World Table in 1990. 
Figure 3.6 Contribution to GDP growth, 1995-2012 (\%)

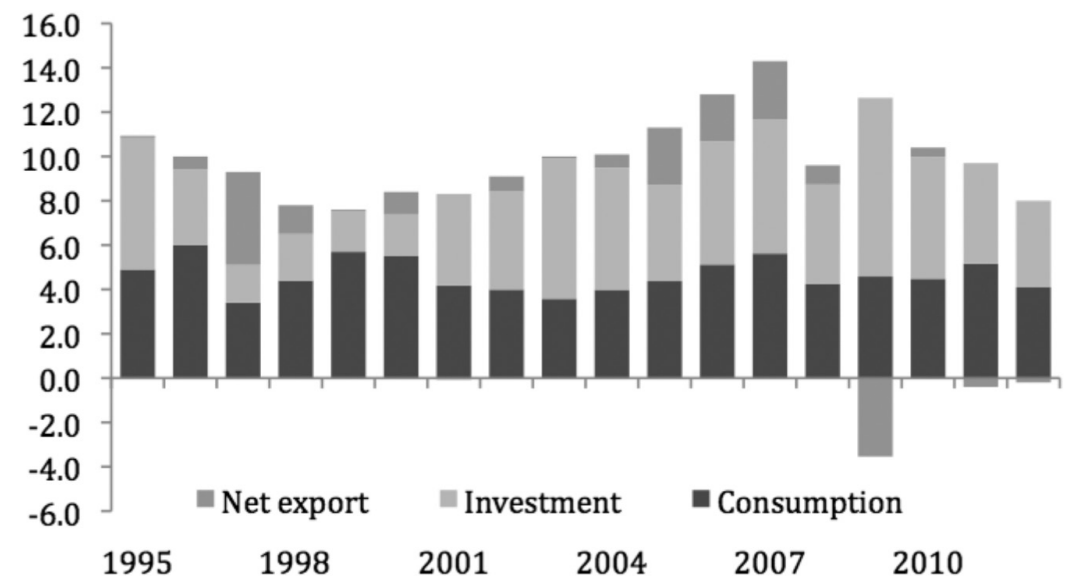

Source: CEIC Data Company.

Recent research finds that the consumption share of GDP began to rise after 2008, although this is not yet fully reflected in official statistics (Huang et al. 2012 and 2013). Huang and his collaborators find that it is difficult to reconcile accelerating retail sales and decelerating consumption in official statistics after 2008. By calculating a new growth rate for consumption, which is a weighted average of consumption-related, retail sales growth and service sales growth, they reveal that the consumption share of GDP fell during much of the past decade, as suggested by official data, but rebounded from 48 per cent in 2008 to 52 per cent in 2010, compared with the official estimate of 47 per cent in that year (Figure 3.7).

Figure 3.7 Total consumption share of GDP (\%)

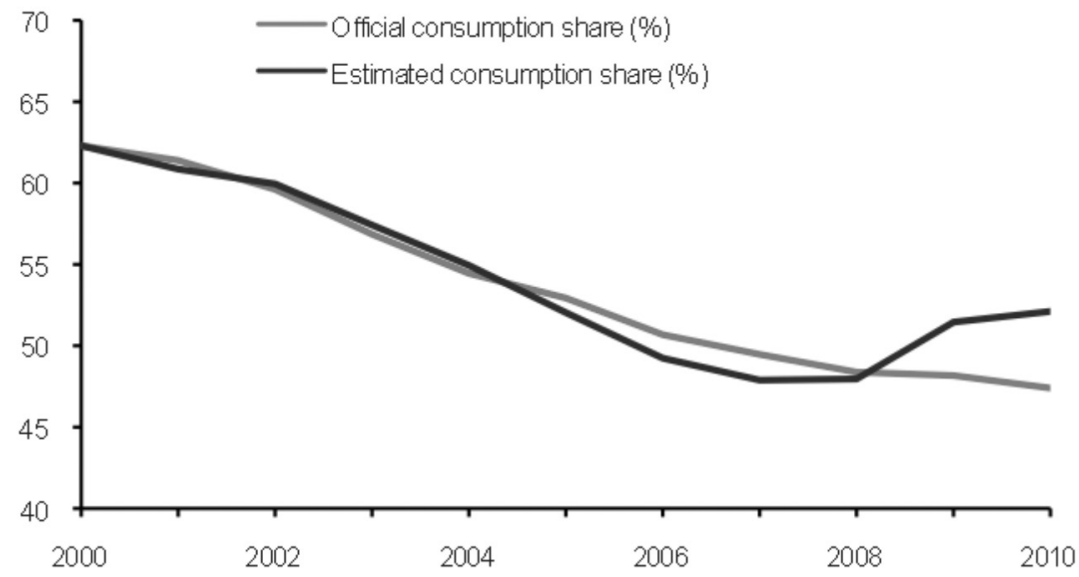


This analysis received sceptical reviews after its initial dissemination. ${ }^{3}$ Some commentators find it difficult to accept our finding, given their strong impression of increasing structural problems following the four trillion yuan stimulus package that was adopted in late 2008. Others argue that structural improvement is impossible, since the government has not undertaken more decisive reforms. The fact that Chinese consumption is probably underestimated, however, is a belief that is shared by an increasing number of Chinese economists. A 2012 study ( $\mathrm{Li}$ and $\mathrm{Xu}$ 2012), for instance, concludes that the household consumption share rebounded from 36 per cent in 2007 to 38.5 per cent in 2011 (Figure 3.8).

Figure 3.8 Household consumption share of GDP (\%)

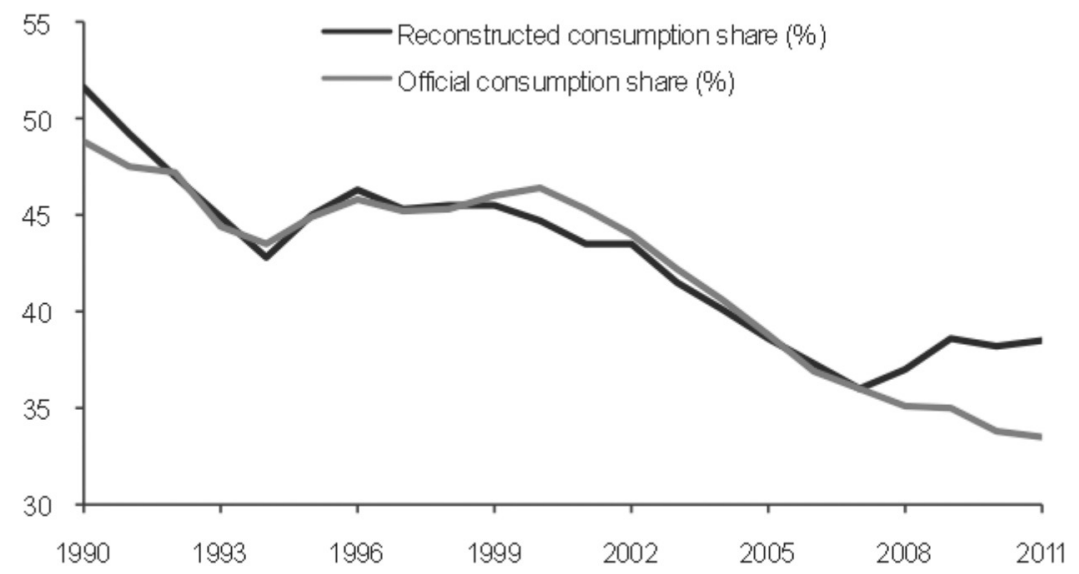

Source: Li and Xu (2012)

\section{Driving Forces Behind the New Normal}

Slower but more sustainable economic growth, and more balanced economic structure, are key features of what we call the 'new normal' of Chinese economic development. Although the government made serious efforts during the past decade, the key factors driving the transition of the Chinese economy are changes in the factor markets, especially in the labour markets. An emerging labour

3 Some articles criticising findings of this study include: 'Optimists' View on China's Economy Suffers from Fatal Flaws' (South China Morning Post, 30 January 2012), 'China is not Rebalancing a) Yet, or b) Enough' (Financial Times, http://ft.com/alphaville), 'China's Rebalancing will not be Automatic' (EastAsiaForum.com). Meanwhile, there were also articles with more sympathetic views, including 'The Incredible Shrinking Surplus: At least One of China's Economic Imbalance is Narrowing' (The Economist, 18 February 2012) and 'All Hail the Chinese Shopper' (Financial News, 27 February 2012 http://www. efinancialnews.com/story/2012-02-27/hail-the-chinese-shopper). 
shortage leads to a rapid increase in wages, which, in turn, slows economic growth, raises inflation pressure, improves income distribution, rebalances economic structure and accelerates industry upgrading (Huang et al. 2011).

Economists have developed diverse analytical frameworks to explain changes in the Chinese economy during the past decades. Justin Lin, Cai Fang and Li Zhou argue that the key to this success was the transition from the heavy industry-oriented to comparative advantage-oriented development strategy (Lin et al. 1995). Barry Naughton introduces the term 'growing out of the plan' to describe China's incremental growth of the market-oriented, private sector, while maintaining support for the old, state-owned enterprises (Naughton 1995). Jeffery Sachs and Wing Thye Woo, however, point out that Chinese economic success can be explained mainly by its convergence with the typical market system of east Asia (Sachs and Woo 2000).

Despite the differences in their perspectives, these economists all agree that the key aspect to the reform is the transition from a centrally planned system to a market system. This is certainly correct, but may only be part of the story. In a series of recent research papers, we argue that the fundamental reason behind the combination of strong economic growth and increasing structural risks is China's asymmetric market liberalisation approach (Huang 2010; Huang and Tao 2010; Huang and Wang 2010). Free markets for products ensure that production decisions are based on demand and supply conditions in the economy, and resources are allocated efficiently. Distortions in factor markets are a way of providing incentives for economic entities and, sometimes, overcoming market failures.

Factor market distortions include the household registration system that limits labour mobility between rural and urban areas; direct controls of bank deposit and lending rates; setting of energy, especially oil, prices by state agencies; and, offering discounted land-use fees to investors. In most cases, these distortions depress input costs. Labour is a special case, however, as it is unclear if labour market segmentation lowers or increases labour cost. But labour cost was low for a long time because of abundant agricultural labour or unlimited labour supply, in a typical Lewis dual-economy.

Low input costs, including low labour costs, are like subsidies to companies, but taxes on households. They boost production profits, increase returns to investment and improve the international competitiveness of Chinese exports. Low input costs also serve as a mechanism for the redistribution of income from households to the companies. Over the years, corporate profits grew much faster than household income, as household income was largely capped by stagnant wage rate. 
Over time, low input costs also contribute to structural problems. Firstly, extraordinary incentives lead to a continuous rise in the shares of exports and investment in GDP. Secondly, a rise of the share of corporate profit in the national income increases the national saving rate, as corporate saving rate is generally higher than household saving rate. Thirdly, income inequality among households deteriorates, as low-income households rely more on wage income while high-income households rely more on corporate profits and investment returns. Fourthly, the consumption share of GDP declines over time because household income grows more slowly than GDP. And, fifthly, the unusually low costs of energy, capital and other resources has also resulted in wasteful behaviour on the part of producers.

The recent transition to the 'new normal' of Chinese economic development is primarily attributable to changes in factor markets. A recent study argues that the distorted factor costs have already started to change (Huang et al. 2011). The labour market shows clear signs of supply shortage, which is evidenced by accelerating wage increases in recent years (Figure 3.9). The development of shadow banking businesses also opens the door for de facto interest rate liberalisation. The Chinese Government has also been trying to reform the price of energy, water and other resources.

The so-called Lewis turning point (LTP) - the transition of the labour market from surplus to shortage - has important implications for China's macroeconomy (Huang and Cai 2010). Rapid wage growth, especially that at the lower end of the market, cuts into profit margin. Therefore, it reverses past redistribution of income from households to corporates. As these implicit subsidies for Chinese companies are reduced, export and investment activities soften and, therefore, the economy rebalances. Applying a computable general equilibrium model of the world economy, Huang and Jiang (2010) analyse detailed economy-wide consequences of the LTP in China.

Figure 3.9 Rapid rise of migrant workers' wages

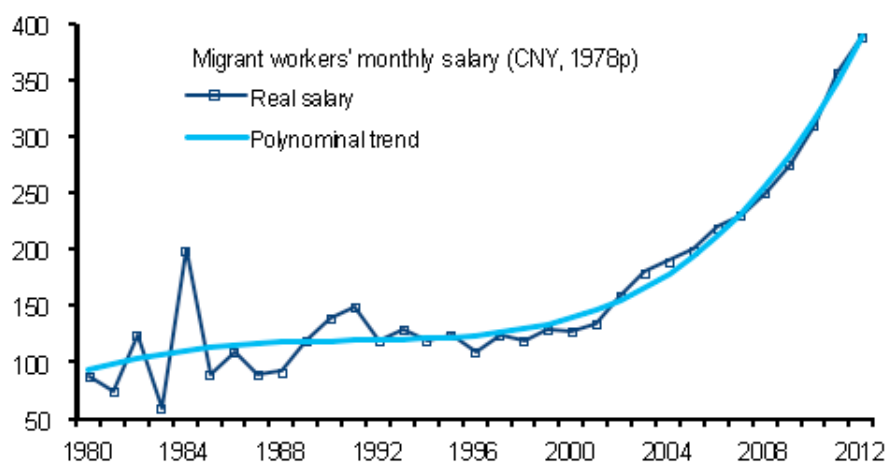


In a sense, it is relatively easy to understand why growth potential has declined in recent years. It is a universal phenomenon that growth slows as an economy develops; this is because the reduced distance from the technological frontier of the developed world means the economy can benefit less from backwardness (Lin 2012). But the growth slowdown is accelerated in China by changing demographics, including labour shortages and a diminishing working-age population. For the same reason, rapidly increasing wages also create inflation pressure, as rising costs can only be absorbed by higher output price, narrower profit margin or faster productivity growth, or a combination of the above.

So, what has contributed to the rising consumption share of GDP in recent years? The answer is household income. When an 'unlimited labour supply' exists, rapid industrialisation is accompanied by a stable wage rate and, therefore, a declining share of wage income in GDP. This is reversed when a labour shortage emerges: wages rise rapidly and the share of wage income in GDP starts to grow. In fact, labour income has also increased from 41 per cent in 2007 to 47.1 per cent in 2009 (Figure 3.10), which, in turn, has boosted consumption relative to GDP. This was also what happened in Korea and Taiwan in the mid 1980s, when their consumption shares started to recover following their respective LTP (Figure 3.11).

Figure 3.10 Labour income and consumption share of GDP (\%)

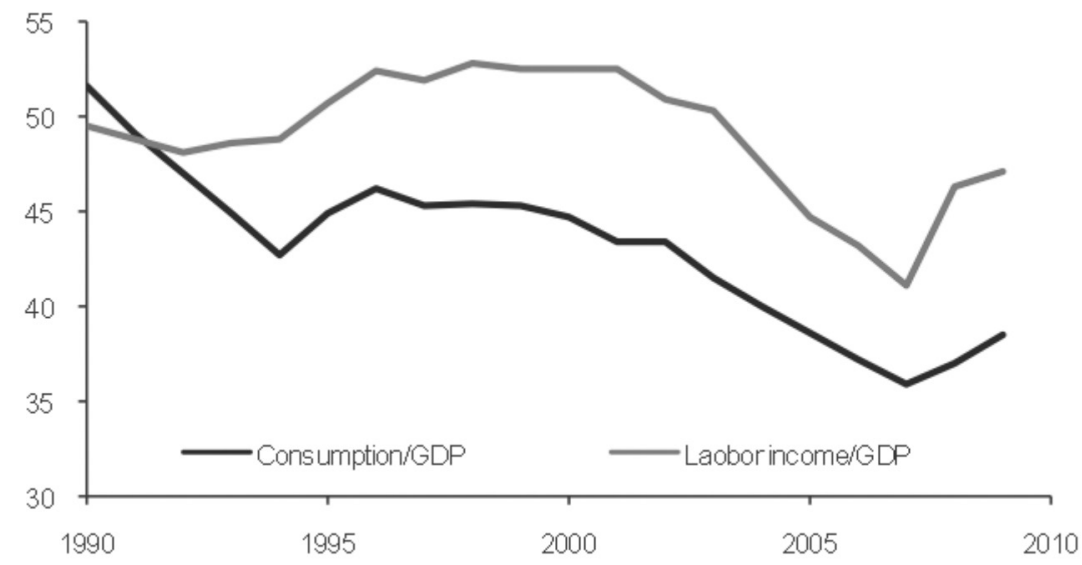

Source: Li and Xu (2012). 
Figure 3.11 Private consumption share of GDP in Korea and Taiwan (\%)

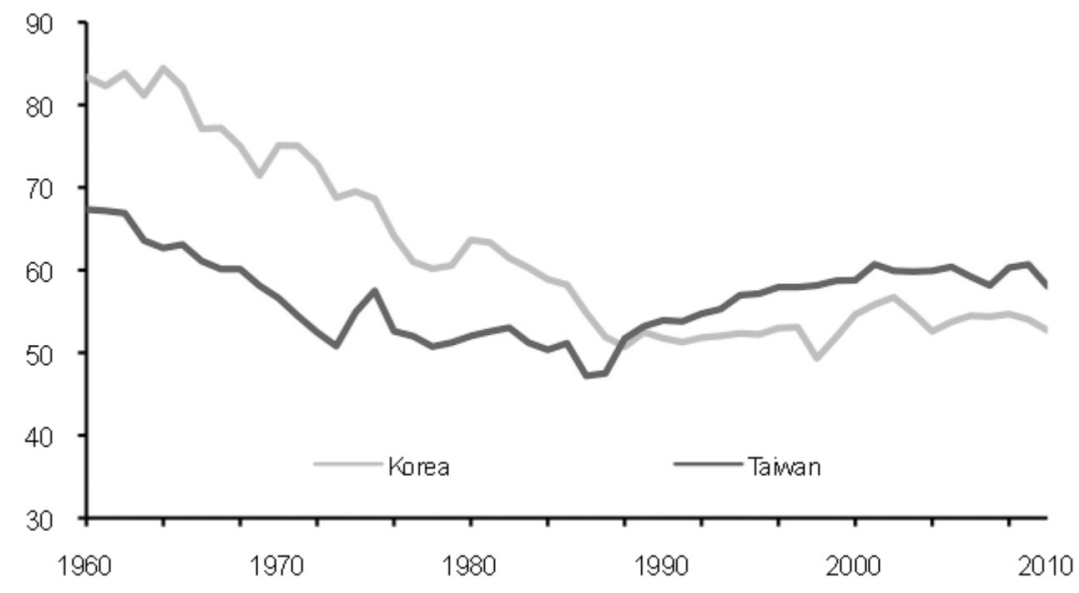

Source: CEIC Data Company.

Rapid wage growth was probably also behind the recent improvements in income distribution highlighted by the NBS, since low-income households rely more on wage income and high-income households rely on investment returns or corporate profits. If the past trend was households subsidising corporations, then the new trend is redistribution of income from corporations to households, as rising labour costs increase wage income but squeeze corporate profits. This is probably why, in rapidly developing economies, the so-called Kuznetz turning point (when income distribution shifts from deteriorating to improving) often follows the Lewis turning point (Huang and Cai 2010).

\section{What's Next?}

Clearly, rebalancing is still at an early stage. For instance, the consumption share of GDP, at 52 per cent in 2010, on our estimates, was significantly below the 70-90 per cent range in most developing and developed economies. This gap may be narrowed, in part, through continuous wage adjustment. Expected liberalisation of interest rates, which will likely lead to high deposit rates, at least, should further facilitate rebalancing. Further changes may also be required to transform the development pattern completely. This could involve measures to improve income equality beyond the primary round of income distribution, development of social welfare systems such as pension, medical insurance and education, and financial and capital account liberalisation.

The first wave of cost shocks - increases in wages - has caused significant economic restructuring. The labour-intensive manufacturing industry in the coastal region is either moving to the western provinces, or migrating to other 
low-cost countries or upgrading along the value chain. Given rapid increases in production costs in inland provinces, it is likely that China will lose its labourintensive industries, especially those export-oriented sectors, faster than many anticipate.

The second wave of cost shocks - increases in costs of capital and energy - may bring about more profound changes to the Chinese economy. Again, normalisation of these costs could reveal massively misallocated resources in the Chinese economy, especially in heavy and highly leveraged industries. Most of these companies are state-owned and were built on a distorted incentive structure. Once costs of capital and energy rise, some of these seemingly profitable companies may become financially unviable. And this would inevitably lead to major industry consolidation, which might bring the first recession to the Chinese economy since the beginning of its economic reform.

This will not, however, necessarily be the beginning of a period of growth stagnation, as some suggest (see, for instance, Pettis 2013). Taking financial repression as an example, it lowers cost of capital in the formal sector, especially for the state-owned enterprises (SOEs). But it also raises the cost of capital outside of the formal sector. Therefore, normalisation of the cost of capital could result in a temporary shrinkage of economic activities in the state sector. At the same time, it might also boost economic activities of the non-state sectors by improving their access to credit and reducing the cost of capital. Importantly, the non-state sectors now account for almost 80 per cent of total industrial output.

Successful transition to the 'new normal' of economic development is only a first step in China's long march toward becoming a high-income country. A bigger challenge facing the Chinese economy now is the so-called 'middle-income trap', as its GDP per capita reaches high middle-income level and its labour cost rises rapidly. The 'middle-income trap' may be defined as the situation that arises when an economy loses competitiveness in low value-added industries, but fails to move up to high value-added industries (Zhuang, Vandenberg and Huang 2012). Chinese industries are already under significant pressure as the three important conditions that facilitate their extraordinary growth in the past - unlimited labour supply, low-cost advantage and rapid export expansion - all diminish steadily. According to the World Bank, only 13 out of 88 middle-income economies succeeded during the past half-century in making the jump to high-income economies (World Bank 2012).

Scepticism about China's ability to continue relatively rapid economic growth is based on several concerns. One main worry is its unsustainable growth model. If the imbalance, inefficiency and inequality problems are not reversed quickly, they could seriously dampen the outlook for the Chinese economy. Unfortunately, as some analysts argue, the policy efforts to improve 
growth quality have achieved little, at least according to the official statistics (Lardy 2012). Others believe that change of the growth model is possible, but it necessarily requires substantially slower growth (Pettis 2013).

Another concern relates to the lack of progress in political reform, alongside market-oriented economic reform. This pattern of reform has led to what Wu Jinglian calls 'state capitalism' ${ }^{4}$ To a large extent, this explains the growing problems of monopoly, corruption and disparity. The SOEs, for example, are a typical example of extractive institutions - they extract monopoly profits by controlling cheap inputs and prohibiting entry into their trade or commerce by others. More importantly, China might be locked into following this path, as it will be hard to reverse, except through extreme social turmoil. Without necessary political reforms to improve political and economic institutions, Chinese growth will sooner or later collapse (Acemoglu and Robinson 2012).

A third difficulty is the potential for Chinese industry to innovate and upgrade. So far, Chinese growth has been driven mainly by low-cost advantage, increasing input and productivity gain through resource reallocation, such as rural-urban migration. But growth based on resource mobilisation is, by definition, not sustainable (Krugman 1994). But can technological innovation replace resource mobilisation to become the main driver of economic growth in China? One obvious hurdle is the low education level of hundreds of millions migrant workers. If they lose low-skill manufacturing and construction jobs, they might not be able to work in high technology and high value-added sectors. Foreign companies also complain that the Chinese legal environment is not conducive to technological innovation because of the lack of proper protection of intellectual property rights in China.

These three concerns are real issues, but they should not be overstated. Rebalancing of the Chinese economy is already underway, although it is not fully appreciated by investors and economists. Completion of rebalancing economy is subject to both further liberalisation of factor markets and additional policy reforms to improve growth quality.

Political reform will be necessary to eradicate corruption and maintain political stability. But it is unlikely that China will adopt a Western-style democracy in the near future, and the current political regime has already exhausted its growth potential. Institutions are vital to enduring growth. But optimal institutions are different for economies at different stages of development. The post-World War II experience of imposing on developing countries the institutions that are best

4 Hu Shuli, 'Fast-track China is on the Wrong Path', 2011, interview with Wu Jinglian, Wall Street Journal, Asia Edition, July 28, http://online.wsj.com/article/SB10001424053111904800304576471393143 140106.html 
suited to developed economies, such as was implemented by the Washington Consensus, was largely unsuccessful. One important reason could be that technological innovation and technological catch-up require different types of institutions - with GDP per capita at US\$6,000, China still has huge potential to gain through technological catch-up.

Even in terms of innovation, China has been doing well. It saw science and technology takeoff much earlier than most other developing countries - it's share of R\&D expenditure of GDP reached one per cent, when its GDP per capita was only US\$3,000, while, on average, other developing countries reached the same level of R\&D expenditure when GDP per capita was US\$8,000. Globally, China is already a leader in terms of total R\&D spending, patent filing and $\mathrm{R} \& \mathrm{D}$ productivity (measured by the number of patent filing divided by $\mathrm{R} \& \mathrm{D}$ expenditure). Continuous technological innovation and industry upgrading are also observed in a large number of industries, including automobile, large machinery and information technology. Protection of intellectual property rights (IPR) is a key drag on progress, but China has a nationwide IPR court system, and the number of IPR cases is increasingly rapidly. According to international experiences, IPR protection will strengthen indigenous innovation so that it becomes a dominant phenomenon.

One major difficulty is to improve labour quality or human capital. As China moves towards becoming a high-income country, industrial upgrading will continuously shift employment from labour-intensive to capital-intensive to technology-intensive sectors. The Chinese experience suggests that shifting workers from labour-intensive to capital-intensive sectors in the secondary industries requires, on average, 1.3 years of additional education. Workers shifting further to technology-intensive sectors in the tertiary industry require 4.2 years' additional education, on average. Human capital accumulation, however, can take place only gradually. For instance, the average number of years of education for the population aged at 16 years and above increased from 6.24 years in 1990 to 7.56 years in 2000, a net increase of 1.32 years. It further increased to 8.9 years in 2010, another net increase of 1.34 years.

Currently, China has a total of 260 million migrant workers, most of whom only finished junior high school. As wages rise rapidly, whether or not these migrant workers will be able to find employment in higher value-added industries will be a critical test for China's 'middle-income trap' challenge. If not, China may end up in not only growth stagnation but also facing massive unemployment problems. Therefore, improving labour quality through education and training should be a policy priority in the coming decades. 


\section{Policy Implications}

Market-oriented economic reforms have been incomplete in China. This, particularly the widespread distortions to factor costs, has contributed to success in economic growth, but has created problems, such as structural risks. Recent changes in factor markets, including emerging labour shortages and rapid wage increases, already slow economic growth and rebalance economic structures, both of which are key features of the 'new normal' of economic development.

This rebalancing trend should not be mixed with some cyclical changes. For instance, while the overall trends are for the investment share of GDP to moderate while the consumption share of GDP rises, at the beginning of 2013, this pattern reversed. The government's policy to stabilise growth inevitably boosts growth, as infrastructure spending is the only swing factor in the near term. Nevertheless, the target is much lower. At the same time, consumption, especially high-end consumer spending, is negatively affected by the government's campaign to crack down on corruption.

These temporary disturbances should not reverse the overall rebalancing trends, unless the government again pushes for investment-led growth. While this is unlikely to happen, the risk is real. The new government is keen to accelerate the urbanisation process, which may lead to further investment. In the meantime, local governments are again planning on massive investment programs. Local investment programs, however, are mainly constrained by their funding capabilities. It is critical for Beijing to keep the brakes on local and central investment programs in order for the rebalancing process to continue.

But, in itself, this is not sufficient. Further policy reforms may be necessary to complete the transition toward the new normal and to avoid the "middle-income trap'. Former president $\mathrm{Hu}$ Jintao suggested that reforms in the next stage should be organised around the central theme of redefining the relationship between the government and the market ( $\mathrm{Hu}$ 2012). In our view, this could include important policies in the following three areas. First, if China had a nomarket economy during the pre-reform period and a half-market economy during the first three decades of the reform period, it is now time to complete the transition to a market economy by removing all the remaining distortions, especially those in factor markets.

Second, China needs to establish a macroeconomic policy framework compatible with an emerging market economy, including an accountable budget system and professional monetary policymaking mechanism. China's macroeconomic policy framework remains administrative in nature. For instance, 
many of the problems associated with the four trillion yuan stimulus package was not the central government's expansionary policy, but investment programs supported or implemented by the banks, the SOEs and the local governments.

And, third, the government's role should shift from directly supporting production and investment through resource mobilisation to facilitating innovation and upgrading via supporting physical and soft infrastructure development. These could include better support to the country's education and research system and improve IPR protection. A critical test in the forseeable future is to upgrade the skills of the large number of migrant workers, most of whom have less than seven years school. It is important to devise training programs so that these workers can move to new industries when their current employers are phased out by rapidly rising costs.

\section{References}

Acemoglu, Daron \& Robsin, James A., 2012, Why Nations fail: The Origins of Power, Prosperity and Poverty, Crown Publishers, New York.

Cai, Fang (ed.), 2007, Reports on China's Population and Labor, No. 8: The Lewisian Turning Point and Policy Challenges (in Chinese), Social Sciences Literature Press, Beijing.

Cai, Fang \& Lu, Yang, 2012, 'At What Rate can Chinese Economy Grow in the Next 10 Years?', (in Chinese) in Jiagui Chen et al. (eds), Chinese Economy Blue Cover Book 2012, Social Science Literature Press.

Cai, Fang \& Wang, Dewen, 2006, 'Employment Growth, Labor Scarcity and the Nature of China's Trade Expansion', in Ross Garnaut \& Ligang Song (eds), The Turning Point in China's Economic Development, Asia Pacific Press, Canberra.

Cai, Fang \& Wang, Meiyan, 2008, 'A Counterfactual Analysis on Unlimited Surplus Labor in Rural China', China \& World Economy, vol. 16, no. 1, pp. 51-65.

Eichengreen, Barry, Park, Donghyun \& Shin, Kwanho, 2011, 'When Fast Growing Economies Slow Down: International Evidence and Implications for China', NBER Working Paper 16919.

Lu, Feng, 2011, 'Employment Expansion and Wage Growth (2001-2010)', China Macroeconomic Research Center, Peking University, Beijing, 12 June. 
Garnaut, Ross \& Huang, Yiping, 2006, 'Continued Rapid Growth and the Turning Point in China's Economic Development', in Ross Garnaut \& Ligang Song (eds), The Turning Point in China's Economic Development, Asia Pacific Press, Canberra.

$\mathrm{Hu}$, Jintao, 2012, 'Firmly March on the Path of Socialism with Chinese Characteristics and Strive to Complete the Building of a Moderately Prosperous Society in all Respects', political report delivered at the 18th national party congress, 8 November 8 , Beijing.

Huang, Yiping, 2004, 'A Labor Shortage in China', Wall Street Journal, A7, 6-8 August.

_ 2010, 'Dissecting the China Puzzle: Asymmetric Liberalization and Cost Distortion', Asia Economic Policy Review, vol. 5, no. 2, pp. 281-95.

, 2012, 'The 'New Normal' of Chinese Growth', East Asia Forum, 14 October, http://www.eastasiaforum.org/2012/10/14/the-new-normal-ofchinese-growth/

Huang, Yiping \& Cai, Fang (eds), 2010, 'Debating China's Lewis Turning Point', China Economic Journal, vol. 3, no. 2.

Huang, Yiping \& Kunyu, Tao, 2010, 'Factor Market Distortion and the Current Account Surplus in China', Asian Economic Papers, vol. 9, no. 3, pp. 1-36.

Huang, Yiping \& Jiang, Tingsong, 2010, 'What Does the Lewis Turning Point Mean for China? A Computable General Equilibrium Analysis', China Economic Journal, vol. 3, no. 2, pp. 191-208.

Huang, Yiping \& Wang, Bijun, 2010, 'Cost Distortions and Structural Imbalances in China', China and World Economy, vol. 18, no. 4, pp. 1-17.

Huang, Yiping, Chang, Jian \& Yang, Lingxiu, 2011, China: Beyond the miracleChina's Next Transition, September, Barclays, Hong Kong.

— 2012, China: Beyond the Miracle - Great Wave of Consumption Upgrading, January, Barclays, Hong Kong.

- 2013, 'Recovery of Consumption and Rebalance of the Economy in China', Asian Economic Papers, vol. 12, no. 1, pp. 47-67.

Krugman, Paul, 1994, 'The Myth of Asia's Miracle', Foreign Affairs, November/ December, vol. 73, no. 6, pp. 62-78. 
Lardy, Nicholas R., 2012, Sustaining China's Economic Growth after the Global Financial Crisis, Peterson Institute of International Economics, Washington DC.

Li, David \& Xu, Sean, 2012, 'The Rebalancing of the Chinese Economy', CCERNBER conference on the Chinese economy, Peking University, 25-26 June, Beijing.

Lin, Justin, 2011, Demystifying the Chinese economy, Cambridge University Press.

Lin, Justin, 2012, The Quest for Prosperity: How Developing Economies Can Takeoff? Princeton University Press.

Lin, Justin, Cai, Fang \& Li, Zhou, 1995, The China Miracle: Development Strategy and Economic Reform, The Chinese University of Hong Kong Press.

Naughton, Barry, 1995, Growing Out of the Plan: Chinese Economic Reform, 1978-1993, Cambridge University Press.

Perkins, Dwight \& Rawski, Thomas G., 2008, 'Predicting the Chinese Economy by 2025', in Loren Brandt \& Thomas Rawski (eds), China's Great Economic Transformation, Cambridge University Press.

Pettis, Michael, 2013, Great Rebalancing: Trade, Conflict, and Perilous Road Ahead for the World Economy, Princeton University Press.

Sachs, Jeffrey D. \& Woo, Wing Thye, 2000, 'Understanding China's Economic Performance', Journal of Policy Reform, Vol. 4, No. 1, pp. 1-50.

Tian, Zhu \& Jun, Zhang, 2012, 'Is China's consumption rate too low?', Finance Times Chinese Website(http://www.ftchinese.com/story/001048246/?print=y).

Wen, Jiabao, 2006, Government Work Report, Delivered at the National People's Congress meeting, 5 March, Beijing.

World Bank \& Development Research Center of the State Council (WB \& DRC), 2012, China: 2030-Building a Modern, Harmonious, and Creative HighIncome Society, March, Washington D.C. \& Beijing.

Yu, Yongding, 2009, 'Chinese policy responses to the global financial crisis', Richard Snape Lecture, 25 November 2009, Productivity Commission, Melbourne, Australia.

Zhuang, Juzhong, 2013, Vandenberg, Paul \& Huang, Yiping, 'Growth Beyond Low-Cost Advantages: Can the People's Republic of China Avoid the MiddleIncome Trap?', October, Asian Development Bank \& Peking University, Manila \& Beijing. 